\title{
PENGARUH PENGGUNAAN BALANCE SCORECARD TERHADAP KINERJA USAHA MIKRO DI SURABAYA
}

\author{
Albertus Daru Dewantoro \\ Fakultas Teknik Universitas Katolik Darma Cendika, J1. Dr. Ir.H. Soekarno No. 201, Surabaya, \\ 57126, Indonesia. \\ Email: albertus.daru@ukdc.ac.id
}

\begin{abstract}
ABSTRAK
Praktek manajerial Kartu Skor Berimbang atau Balanced Scorecard (BSC) pada umumnya digunakan oleh perusahaan besar. Seiring meningkatnya tingkat pendidikan para pelaku usaha mikro, pengimplementasian BSC dalam manajemen usaha mikro semakin meningkat. BSC membantu bisnis dalam menghadapi dua masalah fundamental, yaitu mengukur performa organisasi secara efektif dan mengimplementasikan strategi untuk meningkatkan kinerja. Penelitian ini mengeksplorasi pengaruh penggunaan BSC terhadap kinerja usaha mikro serta mengetahui relasi ukuran perusahaan dengan kemampuan untuk mengimplementasi BSC pada usaha mikro melalui pendekatan statistika deskriptif dan analisa regresi linier. Penelitian dilakukan kepada pelaku usaha mikro di Surabaya dengan kategori memiliki aset atau kekayaan bersih hingga Rp 50 juta (tidak termasuk tanah atau bangunan tempat usaha) dan beromzet penjualan tahunan hingga $\mathrm{Rp} 300$ juta. Total responden dalam penelitian ini adalah sebanyak 153 responden. Penelitian menkonfirmasi bahwa ukuran perusahan memiliki pengaruh pada kesiapan pengimplementasian BSC, hasil ini sejalan dengan penelitian Kimberly \& Evanisko, (1981); Nord \& Tucker, (1987); Hoque, (2000) dan Sherma (2020). Penelitan ini juga membuktikan bahwa semakin besar tingkat implementasi BSC suatu usaha, maka akan semakin tinggi kinerja usaha yang dicapai hal ini sejalan dengan temuan oleh Hoque, (2000); Ondieki, (2017); Dhaifallah, (2018). Ukuran perusahaan mempengaruhi kesiapan usaha mikro dalam mengimplementasikan BSC. Praktek manajerial BSC terbukti mampu meningkatkan kinerja usaha mikro. Praktek BSC membutuhkan kesiapan dengan didukung peningkatan ukuran perusahaan; pelaku usaha mikro hendaknya melibatkan tenaga kerja dalam menjalankan usahanya. Dengan ukuran perusahan yang memadai maka praktik implementasi BSC dapat berjalan optimal dan berdampak pada pencapaian kinerja usaha yang lebih baik.
\end{abstract}

Kata kunci: BSC, Kinerja Usaha, Ukuran Perusahaan, Usaha Mikro 


\begin{abstract}
The Balanced Scorecard (BSC) managerial practice is generally used by large companies. As the education level of micro business actors increases, the implementation of BSC in micro business management is increasing. BSC to help businesses in the face two fundamental problems, which measures the performance of the organization effectively and implement strategies to improve performance. This study explores the effect of using the BSC on the performance of micro-enterprises, as well as knowing the relationship between firm size and the ability to implement the BSC in micro-enterprises through descriptive statistical approaches and linear regression analysis. The study was conducted on micro-enterprises in Surabaya with the category of having assets or net worth of up to IDR 50 million (not including land or building for business premises) and annual sales turnover of up to IDR 300 million. Total respondents in this study is as much as 153 respondents. The study confirmed that the size of the company has an influence on the readiness of the implementation of the BSC, these results are consistent with research Kimberly E Evanisko, (1981); Nord \& Tucker, (1987); Hoque, (2000) and Sherma (2020). This research also shows that the greater the level of BSC implementation of a business, the higher the performance of business achieved in line with the findings by Hoque, (2000); Ondieki, (2017); Dhaifallah, (2018). Company size affects the readiness of micro-enterprises in implementing the BSC. BSC managerial practices proven to improve the performance of microenterprises. BSC practice requires readiness with the support of increasing company size; micro businesses should involve labor in the operations. With an adequate company size, the BSC implementation practice can run optimally and have an impact on achieving better business performance.
\end{abstract}

Keywords: BSC, Business Performance, Firm Size, Micro Enterprise

\section{PENDAHULUAN}

Kartu Skor Berimbang atau Balanced Scorecard (BSC) adalah salah satu praktek manajerial yang paling sering digunakan oleh perusahaan besar, namun tidak sedikit pula usaha mikro, kecil dan menengah (UMKM) juga mengimplementasikan BSC dalam manajemen bisnis mereka. (David \& Ezzamel, 2019). Implementasi BSC pada UMKM di Inggris pada beberapa tahun terakhir ini mengalami peningkatan (Taylor \& Taylor, 2014), hal ini dimungkinkan karena tingkat pendidikan pelaku usaha sektor UMKM adalah para terdidik. Bukti empiris dari pengaruh implementasi BSC pada sektor usaha UMKM jarang ditemukan, namun lebih banyak diperoleh melalui beberapa penelitian yang bersifat studi kasus (Gumbus \& Lussier 2006). Sebagian besar penelitian tentang efektivitas BSC dilakukan pada perusahaan besar dan digunakan untuk membantu perusahaan dalam praktik manajerial mereka guna mencapai tujuan perusahaan (Busco \& Quattrone 2015). Fenomena ini dapat disebabkan oleh beberapa faktor antara lain: kendala sumber daya, terutama pada aspek kemampuan manajemen, UMKM lebih berorientasi pada praktik manajerial yang bersifat rutinitas (Ates et al., 2013), kurangnya jaring pengaman keuangan dan ketergantungan UMKM yang tinggi 
pada pelanggan yang menyebabkan pelaku usaha UMKM tidak terlalu memperhatikan kinerja bisnis (Hudson \& Smith, 2007). Struktur UMKM yang lebih kecil dan fleksibel menyebabkan pemilik usaha mengharuskan karyawan untuk melakukan berbagai peran dalam proses bisnisnya dengan batasan tanggung jawab pekerjaan yang tidak jelas. Sistem kompensasi dan penilaian kinerja karyawan kurang diformalkan dan obyektif (Cardon \& Stevens, 2004).

Penelitian ini mengeksplorasi pengaruh penggunaan BSC terhadap kinerja usaha mikro. Atkinson et al., (1997) mengemukakan bahwa BSC memiliki potensi untuk memberi para perencana cara menguji model sebab akibat yang relevan dalam organisasi, model tersebut dapat digunakan pelaku usaha dalam mengelola faktor-faktor penting dalam kinerja usaha mikro. BSC memandang kinerja organisasi dari empat dimensi, yaitu dimensi keuangan, pelanggan, proses bisnis internal, dan pembelajaran dan pertumbuhan. Perspektif keuangan merupakan tujuan dan ukuran kinerja terkait dengan persepsi dan harapan pemodal terhadap organisasi (MacKay \& Phillips, 2005). Ukuran keuangan mengungkapkan kinerja yang dicapai oleh organisasi (Christesen, 2008). Perspektif pelatihan dan pertumbuhan adalah upaya yang direncanakan oleh organisasi untuk memfasilitasi pembelajaran karyawan tentang kompetensi terkait pekerjaan yang mencakup pengetahuan, keterampilan, atau perilaku yang penting untuk kinerja pekerjaan yang sukses. Pelatihan dan pengembangan membantu

mengoptimalkan penggunaan sumber daya manusia dalam upaya mencapai tujuan organisasi serta tujuan individu (Abiodun et al., 2014). Perusahaan harus mampu, memperluas dan meningkatkan kepuasan pelanggan serta loyalitas pelanggan dalam situasi persaingan pasar baru dalam meningkatkan kinerjanya ( $\mathrm{Li}$ et al., 2009). Untuk mendapatkan keunggulan kompetitif, organisasi menggunakan strategi yang tidak hanya berorientasi pada biaya dan harga, akan tetapi yang terpenting adalah memperhitungkan pemenuhan ekspektasi pelanggan (Li et al., 2009). Budaya organisasi merupakan norma organisasi yang mencerminkan pengaruh kreativitas dan inovasi, hal ini memiliki peran penting dalam menciptakan lingkungan yang memungkinkan pembelajaran dan inovasi untuk merespons tantangan atau ancaman serta peluang baru. Organisasi harus menciptakan budaya adaptif yang memungkinkan program pelatihan dan pengembangan dalam memanfaatkan peluang. Sikap karyawan dinilai memiliki peran penting dalam menentukan kinerja organisasi dalam jangka panjang serta untuk mencapai tujuan, misi dan visi organisasi (Barma \& Gupta 2015). Sikap dapat muncul dari tiga faktor utama yaitu faktor organisasi, faktor kelompok dan faktor pribadi (Griffin et al., 1981).

Penelitian ini mengekplorasi ukuran perusahaan dengan implementasi BSC pada usaha mikro. Ukuran organisasi merupakan faktor penting yang mempengaruhi adopsi sistem kontrol yang lebih kompleks 
(Chenhall \& Langfield, 1998). Beberapa penelitian melaporkan hubungan positif antara ukuran perusahaan dan penggunaan BSC (Sharma \& Sharma, 2020; Hoque \& James, 2000; Devish \& Umesh; 2020). Beberapa literature membuktikan bahwa ukuran perusahaan berpengaruh positif terhadap kinerja inovasi, karena organisasi yang memiliki ukuran yang lebih besar memiliki lebih banyak sumber daya keuangan, modal SDM dan kemampuan pengembangan produk (Subramony et al., 2018). Oleh karena itu, kami mengharapkan ukuran perusahaan memiliki pengaruh positif dengan penggunaan BSC.

\section{METODE}

Penelitian ini menggunakan metode survei berbasis kuesioner yang dilakukan untuk mengumpulkan data dan informasi yang dibutuhkan terkait penelitian usaha mikro di Surabaya. Responden adalah pelaku usaha mikro dengan ketentuan usaha perorangan yang memiliki kriteria sesuai Undang-Undang (UU) Nomor 20 Tahun 2008 tentang Usaha Mikro, Kecil dan Menengah, yakni:

1. Memiliki aset atau kekayaan bersih hingga Rp 50 juta, tidak termasuk tanah atau bangunan tempat usaha.

2. Omzet penjualan tahunan hingga Rp 300 juta.

Survei berbasis kuesioner telah hal yang umum dalam penelitian yang dibuat dengan mengadopsi dan membandingkan dengan studi-studi sebelumnya. Kuesioner dikirim melalui survei lapangan langsung ke usaha mikro di Surabaya. Usaha mikro ini dipilih secara acak dari berbagai jenis usaha. Lima puluh dua dari dari 150 kuesioner dikirim dalam pengiriman pertama yang bersedia diisi dan dikembalikan. Untuk survey kedua menghasilkan 112 kuesioner yang dikembalikan dari 200 pelaku usaha yang dikirimi form kuisioner. Dari $164 \quad$ kuisioner yang dikembalikan, terdapat 11 responden tidak mengisi secar baik dan benar, sehingga total responden dalam penelitian ini adalah sebanyak 153 responden.

Instrument pengukuran variable ukuran perusahaan kami akan mengukur melalui omzet penjualan, total asset dan jumlah pegawai dari UMKM dengan merujuk pada penelitian yang digunakan oleh Hoque (2000). Untuk instrument variable penggunaan BSC, penelitian ini menggunakan 20 item pertanyaan yang meliputi 3 item pertanyaan untuk dimensi finansial, 6 item pertanyaan untuk dimensi proses bisnis internal, 3 item pertanyaan untuk dimensi pertumbuhan dan pembelajaran, sedangakan untuk dimensi fokus pada penglanggan diukur dengan 8 item pertanyaan, dimana responden diminta untuk menunjukkan sejauh mana setiap item digunakan untuk menilai kinerja organisasi mereka menggunakan skala Likert lima poin mulai dari 1 (tidak sama sekali) hingga 5 ( tingkat penggunaan yang tinggi), instrument tersebut mengadaptasi penelitian yang dilakukan oleh Hoque, (2000). Variable hasil yaitu kinerja usaha, pada penelitian ini mengadaptasi instrument yang digunakan oleh Li et all. (2009), dimana pengukuran kinerja bisnis didasarkan tingkat 
penjualan tahunan dan pada pertumbuhan jumlah karyawan tahun saat ini dibandingkan dengan tahun yang lalu. Responden diminta untuk menunjukkan kinerja organisasi mereka dibandingkan dengan pesaing mereka dalam lima dimensi di atas dalam skala dari $1=$ di bawah ratarata hingga $5=$ di atas rata-rata

Penentuan kuesioner dinyatakan absah pada penelitian ini dilakukan melalui uji validitas dan reliabilitas instrumen. Teknik analisis data yang digunakan adalah analisis deskriptif, analisis regresi sederhana dan regresi bertingkat menggunakan softwere SPSS 17. Analisis regresi bertingkat digunakan untuk mengukur seberapa besar dampak yang ditimbulkan variabel mediasi terhadap relasi antara variabel bebas dengan variabel terikat.

\section{HASIL DAN PEMBAHASAN}

\section{Profil Responden}

\subsection{Jenjang Pendidikan Responden dan Implementasi BSC}

Pengetahuan tentang BSC diberikan pada strata pendidikan sarjana, namun dengan perkembangan sumber literasi pengatahuan secara online, tidak menutup kemungkinan konsep BSC sebagai praktek manajerial dapat dipahami dengan mudah oleh segenap kalangan. Tabel 1 memberikan gambaran bahwa pelaku usaha mikro dengan tingkat pendidikan sarjana atau jenjang yang lebih tinggi memiliki tingkat implementasi BSC yang lebih tinggi pada proses manajerial usahanya, hal ini sesuai dengan pendapat Taylor \& Taylor, (2014).

Tabel 1. Tingkat Implementasi BSC Usaha Mikro Didasarkan Jenjang Pendidikan Pelaku Usaha

\begin{tabular}{|c|c|c|}
\hline \multirow{2}{*}{$\begin{array}{c}\text { Tingkat } \\
\text { Pendidikan }\end{array}$} & \multicolumn{2}{|c|}{$\begin{array}{c}\text { Tingkat Implementasi } \\
\text { BSC }\end{array}$} \\
\hline & $1,00-2,50$ & $>2,51$ \\
\hline $\begin{array}{c}\text { SMA dan } \\
\text { jenjang } \\
\text { dibawahnya }\end{array}$ & 30 & 8 \\
\hline $\begin{array}{c}\text { Sarjanan dan } \\
\text { jenjang } \\
\text { diatasnya }\end{array}$ & 23 & 92 \\
\hline
\end{tabular}

\subsection{Jumlah Karyawan}

Dari 153 responden penelitian ini, jumlah tenaga kerja yang paling sedikit adalah dua karyawan dan terbanyak adalah 12 tenaga kerja. Usaha mikro sebagian besar dilajankan oleh kerabat dan tidak memiliki batasan spesifikasi tugas dalam pekerjaan.

Tabel 2. Jumlah Tenaga Kerja

\begin{tabular}{cc}
\hline Jumlah Karyawan & Frequency \\
\hline 2,00 & 21 \\
3,00 & 23 \\
4,00 & 16 \\
5,00 & 11 \\
6,00 & 17 \\
7,00 & 23 \\
8,00 & 27 \\
9,00 & 12 \\
10,00 & 2 \\
12,00 & 1 \\
Total & 153 \\
\hline
\end{tabular}

\section{Analisa Deskriptif}

Berikut adalah hasil analisis deskriptif tiap-tiap variable penelitan. 
Tabel 3. Analisa Deskriptif

\begin{tabular}{lccc}
\hline & N & Mean & $\begin{array}{c}\text { Std. } \\
\text { Deviation }\end{array}$ \\
\hline $\begin{array}{l}\text { Perspektif } \\
\begin{array}{l}\text { Finansial } \\
\text { Perspektif }\end{array}\end{array}$ & 153 & 3,5229 & 0,54312 \\
$\begin{array}{l}\text { Proses Bisnis } \\
\text { Perspektif }\end{array}$ & 153 & 2,8290 & 0,75291 \\
$\begin{array}{l}\text { Pembelajaran } \\
\text { \& }\end{array}$ & 153 & 1,5316 & 0,49329 \\
$\begin{array}{l}\text { Pertumbuhan } \\
\text { Perspektif }\end{array}$ & 153 & 2,6364 & 0,39460 \\
$\begin{array}{l}\text { Pelanggan } \\
\text { Implementasi }\end{array}$ & 153 & 2,6300 & 0,50240 \\
$\begin{array}{l}\text { BSC } \\
\text { Kinerja }\end{array}$ & 153 & 2,2157 & 0,55240 \\
Jumlah & 153 & 5,5490 & 2,42504 \\
$\begin{array}{l}\text { Karyawan } \\
\text { Omset* }\end{array}$ & 153 & 117,1503 & 35,49329 \\
Aset* & 153 & 38,2810 & 10,43870 \\
\hline
\end{tabular}

* Dalam juta rupiah

\section{Analisa Korelasi}

Analisis korelasi adalah metode statistika yang digunakan untuk menentukan kuatnya atau derajat hubungan linier antara dua variabel atau lebih. Semakin nyata hubungan linier (garis lurus), maka semakin kuat atau tinggi derajat hubungan garis lurus antara kedua variabel atau lebih. Ukuran untuk derajat hubungan garis lurus ini dinamakan koefisien korelasi.

Tabel 4. Analisa Korelasi

\begin{tabular}{lccc}
\hline \multicolumn{3}{c}{ Correlations } \\
\hline & $\begin{array}{c}\text { Jml } \\
\text { Karya } \\
\text { wan }\end{array}$ & $\begin{array}{c}\text { Impl. } \\
\text { BSC }\end{array}$ & Kinerja \\
\hline $\begin{array}{l}\text { Jumlah } \\
\text { Karyawan } \\
\text { Implement } \\
\text { asi BSC } \\
\text { Kinerja }\end{array}$ & 1 &, $968^{* *}$ &, $861^{* *}$ \\
\hline **. Correlation is significant at the 0.01 \\
level (2-tailed).
\end{tabular}

Tabel 4 di atas menunjukkan bahwa hubungan antar variable yang ditunjukkan melalui Korelasi Pearson, koefisien yang muncul pada Tabel 4 . sesuai dengan yang diharapkan, dimana implementasi BSC berkorelasi signifikan dengan ukuran organisasi yang direpresentasikan dengan jumlah karyawan $(\mathrm{r}=0,968, \mathrm{p}<0,05)$, dan kinerja usaha $(r=0,863, p<0,05)$ hal ini sejalan dengan penelitian yang dilakukan oleh Hoque, (2000) dan Sharma (2020).

\section{Analisa Regresi}

\subsection{Relasi Ukuran Usaha dan Implementasi BSC}

Variabel kontekstual, ukuran organisasi yang meliputi jumlah karyawan, omset dan aset tidak berhubungan secara signifikan satu sama lain, menunjukkan bahwa multikolinearitas tidak terjadi. Pengujian multikolinieritas melalui faktor toleransi dan varians inflasi (VIF) yang disajikan pada Tabel 5 mengungkapkan bahwa multikolinearitas tidak menimbulkan masalah dalam menginterpretasikan hasil ini.

Tabel 5. Analisa Regresi Model 1 : Ukuran Perusahaan - Implementasi BSC

\begin{tabular}{|c|c|c|c|c|}
\hline & $\begin{array}{c}\text { Coeffic } \\
\text { ients - } \\
\text { Beta }\end{array}$ & $\mathrm{t}$ & Sig. & VIF \\
\hline Jml & & & & \\
\hline $\begin{array}{l}\text { Karya } \\
\text { wan }\end{array}$ & 681 & 7,348 & 000 & 4,661 \\
\hline Omset & ,325 & 5,725 & 000 & 9,229 \\
\hline Aset & -,020 &,- 280 & 780 & 5,177 \\
\hline
\end{tabular}


Tabel 5 menunjukkan hasil analisis regresi model pertama. Model regresi keseluruhan untuk ketiga kontekstual variabel menjelaskan persen dari varians dependen variabel $(p=0,000)$. Data menunjukkan bahwa beta standar koefisien $\beta 1$ (jumlah karyawan) dan $\beta 2$ (omset) keduanya positif dan signifikan $(\beta 1=0,861, \mathrm{p}=0,000 ; \beta 2=$ $0,325, \mathrm{p}=0,000)$. Meskipun koefisien $\beta 3$ (asset) negative dan tidak signifikan secara statistik $(\beta 3=-0,20$, $\mathrm{p}=0,780)$. Hasil tersebut menunjukkan bahwa BSC semakin besar penggunaan dikaitkan dengan ukuran organisasi yang lebih besar, hal ini sejalan dengan pemikiran dari Hoque, (2000) dan Sharma (2020).

Pada penelitian ini secara khusus menunjukkan bahwa ukuran organisasi pada aspek jumlah karyawan dan omset memiliki pengaruh positif dan signifikan, sedangkan ukuran organisasi dari aspek besarnya aset tidak signifikan mempengaruhi tingkat implementasi BSC.

\subsection{Implementasi BSC dan Kinerja Usaha}

Tabel 6. Analisa Regresi Model 2: Implementasi BSC-Kinerja Usaha Mikro

\begin{tabular}{ccccc}
\hline & $\begin{array}{c}\text { Coeffici } \\
\text { ents - } \\
\text { Beta }\end{array}$ & t & Sig. & VIF \\
\hline $\begin{array}{l}\text { Imple } \\
\text { menta } \\
\text { si BSC }\end{array}$ & 0,853 & 20,06 &, 000 & 1,000 \\
\hline
\end{tabular}

Adjusted $\mathrm{R}^{2}=0.725, \mathrm{p}=0.000$

a. Dependent Variable: Kinerja Usaha

b. Predictors: Implementasi BSC

Tabel 6 menunjukkan hasil analisis regresi model kedua. Model regresi keseluruhan untuk mono kontekstual variabel menjelaskan persen dari varians di dependen variabel $(p=0,000)$. Data menunjukkan bahwa beta standar koefisien $\beta 1$ (Implementasi BSC) positif dan signifikan $(\beta 1=0,853, p=0,000)$. Hasil tersebut menunjukkan bahwa kinerja usaha pada penggunaan/ implementasi BSC yang lebih besar. Penelitian ini sejalan dengan apa yang disampaikan oleh Hoque, (2000).

\section{KESIMPULAN}

Hasil penelitian menkonfirmasi penelitian terdahulu bahwa, ukuran perusahan memiliki pengaruh pada kesiapan pengimplementasian BSC, khususnya ukuran perusahan yang dilihat dari jumlah karyawan dan omset tahunan yang diperoleh. Pengimplementasian BSC tidak signifikan berpengaruh pada peningkatan aset.. Penelitan ini juga membuktikan bahwa semakin besar tingkat implementasi BSC suatu usaha, maka akan semakin tinggi kinerja usaha yang dicapai dengan diukur melalui tingkat penjualan dan tingkat pertumbuhan karyawan.

\section{DAFTAR PUSTAKA}

Abiodun, Abolaji, J., Omotayo, A. O., Adenike, A. A., and Emmanuella, I. (2014). Modelling the Relationship between Job Demands, Work Attitudes and Performance among Nurses in a Transition Economy. International Journal of Healthcare Management 7(4): 257-64.

Ates, A., Patrizia, G., Paola, C., and Umit, B. (2013). The Development of SME Managerial Practice for 
Effective Performance

Management. Journal of small business and enterprise development.

Atkinson, A.A., Ramji, B., Peter, B., and Jane, M. C. (1997). New Directions in Management Accounting Research. Journal of management accounting research 9: 79.

Barma, D. D., and Meenakshi G. (2015). Investigating the Effectiveness of the Sources of Recruitment on Job Performance and Employee Attitude in India. Asian Journal of Management 6(1): 67-71.

Busco, C., and Paolo, Q. (2015). Exploring How the Balanced Scorecard Engages and Unfolds: Articulating the Visual Power of Accounting Inscriptions. Contemporary Accounting Research 32(3): 1236-62.

Cardon, M. S., and Christopher, E. S. 2004. Managing Human Resources in Small Organizations: What Do We Know? Human Resource Management Review 14(3): 295323.

Chenhall, R.H, and Kim L. (1998). Adoption and Benefits of Management Accounting Practices: An Australian Study. Management accounting research 9(1): 1-19.

Christesen, D.A. (2008). The Impact of Balanced Scorecard Usage on Organization Performance. University of Minnesota.

David, J. C., Mahmoud, E., Sandy, Q. Q. (2019). Popularizing a
Management Accounting Idea: The Case of the Balanced Scorecard. Journal of Chemical Information and Modeling 53(9): 1689-99.

Griffin, R.W., Ann, W., and Gregory, M. (1981). Perceived Task Characteristics and Employee Performance: A Literature Review. The Academy of Management Review 6(4): 655.

Gumbus, A., and Robert, N. L. (2006). Entrepreneurs Use a Balanced Scorecard to Translate Strategy into Performance Measures What Is a BSC and Why Should Small. Journal of Small Business Management 44(3): 407-25.

Hoque, $Z$ and Wendy, J. (2000). Linking Balanced Scorecard Measures to Size and Market Factors: Impact on Organizational Performance. Journal of Management Accounting Research 12(1): 1-17.

Hudson, S, M and Dave, S. (2007). Implementing Strategically Aligned Performance Measurement in Small Firms. International Journal of Production Economics 106(2): 393-408.

Li, Y., Jiafu, T., Xinggang, L., and Jie, X. (2009). An Integrated Method of Rough Set, Kano's Model and AHP for Rating Customer Requirements' Final Importance. Expert Systems with Applications 36(3): 7045-53.

MacKay, P., and Gordon, M. P. (2005). How Does Industry Affect Firm Financial Structure? Review of Financial Studies 18(4): 1433-66. 
Sharma, D., and Umesh S. (2020). Analysis of Balanced Scorecard Usage by Private Companies. Pacific Accounting Review.

Subramony, M., Jesse. S., Clint C., and Aarti, S. (2018). Leadership Development Practice Bundles and Organizational Performance: The Mediating Role of Human Capital and Social Capital. Journal of Business Research 83(December 2016): 120-29. https://doi.org/10.1016/j.jbusres .2017.09.044.

Taylor, A, and Margaret, T. 2014. Factors Influencing Effective Implementation of Performance Measurement Systems in Small and Medium-Sized Enterprises and Large Firms: A Perspective from Contingency Theory. International Journal of Production Research 52(3): 847-66. 